\title{
Pelvic circumferential compression devices for prehospital management of suspected pelvic fractures: a rapid review and evidence summary for quality indicator evaluation
}

Robin Pap ${ }^{1,2^{*}}$, Rachel McKeown ${ }^{2}$, Craig Lockwood ${ }^{1}$, Matthew Stephenson ${ }^{1}$ and Paul Simpson ${ }^{2}$

\begin{abstract}
Background: Pelvic fractures, especially when unstable, may cause significant haemorrhage. The early application of a pelvic circumferential compression device (PCCD) in patients with suspected pelvic fracture has established itself as best practice. Ambulance services conduct corresponding performance measurement. Quality indicators (Qls) are ideally based on high-quality evidence clearly demonstrating that the desirable effects outweigh the undesirable effects. In the absence of high-quality evidence, best available evidence should be combined with expert consensus.
\end{abstract}

Objectives: The aim of the present study was to identify, appraise and summarize the best available evidence regarding PCCDs for the purpose of informing an expert panel tasked to evaluate the validity of the following Ql: A patient with suspected pelvic fracture has a PCCD applied.

Methods: A rapid review of four databases was conducted to identify relevant literature published up until 9 June 2020. Systematic reviews, experimental, quasi-experimental and observational analytic studies written in English were included. One author was responsible for study selection and quality appraisal. Data extraction using a priori extraction templates was verified by a second reviewer. Study details and key findings were summarized in tables.

Results: A total of 13 studies were assessed to be eligible for inclusion in this rapid review. Of these, three were systematic reviews, one was a randomized clinical trial (crossover design), two were before-after studies, and seven were retrospective cohort studies. The systematic reviews included mostly observational studies and could therefore not be considered as high-level evidence. Overall, the identified evidence is of low quality and suggests that PCCD may provide temporary pelvic ring stabilization and haemorrhage control, although a potential for adverse effects exists.

Conclusion: Given the low quality of the best available evidence, this evidence would need to be combined with expert consensus to evaluate the validity of a related quality indicator before its implementation.

Keywords: Pelvic fracture, Trauma, Prehospital care, Rapid review, Quality indicator

\footnotetext{
* Correspondence: r.pap@westernsydney.edu.au

'Joanna Briggs Institute, University of Adelaide, Adelaide, Australia

${ }^{2}$ School of Health Sciences, Western Sydney University, Sydney, Australia
}

(c) The Author(s). 2020 Open Access This article is licensed under a Creative Commons Attribution 4.0 International License, which permits use, sharing, adaptation, distribution and reproduction in any medium or format, as long as you give appropriate credit to the original author(s) and the source, provide a link to the Creative Commons licence, and indicate if changes were made. The images or other third party material in this article are included in the article's Creative Commons licence, unless indicated otherwise in a credit line to the material. If material is not included in the article's Creative Commons licence and your intended use is not permitted by statutory regulation or exceeds the permitted use, you will need to obtain permission directly from the copyright holder. To view a copy of this licence, visit http://creativecommons.org/licenses/by/4.0/. The Creative Commons Public Domain Dedication waiver (http://creativecommons.org/publicdomain/zero/1.0/) applies to the data made available in this article, unless otherwise stated in a credit line to the data. 


\section{Background}

Exsanguinating haemorrhage is one of the leading causes of death in patients suffering major trauma [1]. Besides catastrophic external haemorrhage, blood loss may occur from thoracic, abdominal, pelvic or limb injuries. Any of these alone or in combination can produce significant hypovolemia. Especially injury to the bony pelvis with disruption of the pelvic ring and damage to adjacent blood vessels may cause severe bleeding and can be associated with considerable morbidity and mortality [24]. As substantial force is required to cause fracture of the pelvic ring, some of the most frequent mechanisms of this injury involve road traffic accidents, falls from height and localized crush injuries $[5,6]$. However, in the elderly with osteoporosis, disruption of the pelvic ring can also occur from low-energy mechanism [7]. Pelvic ring fractures may be classified in a number of ways. Most commonly, the Tile [8] and Young-Burgess [9] classification systems are used. These divide pelvic ring injuries into various types based on stability/instability of the posterior sacroiliac complex (Tile type A: stable, Tile type B: rotationally unstable, Tile type $\mathrm{C}$ : vertically and rotationally unstable) and vector of injuring force (lateral compression types, anterior-posterior types, vertical shear types and combined mechanisms) respectively. Considering the potentially life-threatening haemorrhage associated with pelvic ring fractures, rapid identification and management are critical to optimize patient outcomes.

Historically, prehospital management in the form of pelvic binding was performed when inspection and palpation of the pelvis revealed deformity, instability and pain. However, the diagnostic reliability of identifying a pelvic fracture by physical examination is questionable, particularly in the patient with decreased level of consciousness [10-12]. Furthermore, manipulating and especially springing the pelvis carries significant risk of disrupting any clot that may have formed and thus interfering with any spontaneous haemostasis [11]. Therefore, the decision to apply a pelvic circumferential compression device (PCCD) in any blunt trauma patient with suspected pelvic ring fracture based predominantly on the mechanism of injury and any visual signs such as bruising around the pelvis is increasingly being advocated as best practice in the prehospital care [13-15]. As the name implies, the intended purpose of a PCCD is to wrap around and stabilize the pelvic ring thereby limiting haemorrhage from cancellous bone or venous sources. The placement of a PCCD on a patient with a mechanism of injury suggestive of pelvic ring disruption is now commonly regarded to be an indicator of highquality prehospital trauma care [13-15]. As such, many ambulance services utilize this quality indicator (QI) in the measurement of their clinical performance [16].
A QI is an explicitly defined and measurable aspect of health care services indicative of a desirable structure, process or outcome [17]. That is to say, there is evidence and/or consensus that the indicator can be used to quantify the quality of service provided, and thus monitor changes in quality over time [18]. This measurement provides a tool to identify unwarranted variation, facilitate data-driven improvement efforts and assess their impact. Systematically developed QIs are ideally based on scientific evidence. This may stem from rigorously developed guidelines $[19,20]$, but preferably is based directly upon high-quality scientific evidence such as thoroughly conducted (trial-based) empirical studies or robust systematic reviews and meta-analyses of randomized controlled trials (RCT) $[17,21]$. In areas or disciplines where such evidence is scarce, it may be necessary to combine the best available evidence with expert consensus $[17,22]$. Since the methodical review of underpinning evidence is fundamental to the systematic development of quality indicators, the expert consensus process should also be evidence-informed. The RAND/ UCLA appropriateness method (RAM) is a formal group judgement process developed in the 1980 s by the Research and Development (RAND) Corporation and the University of California, Los Angeles (UCLA) [23]. It combines expert opinion and scientific evidence in the form of systematic literature reviews by asking panellists to rate, discuss, and then re-rate statements.

However, this prominent advantage that RAM has over other consensus processes may also be a deterring factor. A systematic review is conducted to provide the expert panel with all pertinent information that will guide evidence-based decision-making [23]. Due to the rigorous methods applied when conducing full systematic reviews, they can take an extensive period of time to complete $[24,25]$. This may be particularly problematic when multiple areas are being covered, there is high complexity in the topic, or both. Rapid reviews are a form of knowledge synthesis in which components of the systematic review process are simplified or omitted to produce information in a more timely manner [26]. As such, rapid reviews may offer a time- and resourceefficient alternative to modify RAM and prevent a potentially protracted and misaligned decision timeline. Although the rapid review approach has several inherent limitations, it may be a suitable compromise to facilitate swift synthesis of available evidence and adequately inform decisions in a RAM expert consensus process.

The aim of the present study was to apply rapid review methods to identify, appraise and summarize the best available evidence regarding PCCDs and in doing so provide an evidence summary to inform an expert panel tasked to validate the QI used for the measurement of prehospital trauma care quality. More specifically, this 
rapid review aimed to investigate current evidence for the effectiveness and safety of non-invasive PCCDs. This study forms part of a larger research project aimed at developing and testing prehospital care quality indicators for the Australian setting (https://www.aspireproject.net).

\section{Methods}

\section{Preliminary work}

As the initial part of the larger research project, a scoping review was conducted in accordance with Joanna Briggs Institute (JBI) methodology [16]. The scoping review's purpose was to map the attributes of 'quality' in the context of prehospital care, to chart existing international prehospital care QIs and explore their development processes. Identified QIs were categorized as either system/organizational/non-clinical (domain A) or clinical (domain B). Within these two domains, several subdomains were formed, including 'trauma care' (sub-domain B.6). QIs describing in one way or another the application of a PCCD in a patient with suspected pelvic fracture were identified in several included articles and aggregated into one single QI concisely describing the specific clinical intervention (Table 1). Furthermore, the QI was labelled as a process indicator according to Donabedian's model, and as a QI primarily addressing 'effectiveness', one of the attributes of 'quality' mapped in the review.

\section{Rapid review \\ Literature search strategy}

Guided by the approaches to rapid reviews and evidence summaries by JBI and the World Health Organization (WHO) [27], a rapid systematic literature review was conducted to develop a summary of the best available evidence concerning the placement of a PCCD in the prehospital environment. Systematic searches of four electronic databases (the Cochrane Library, the JBI Database of Systematic Reviews, PubMed and CINAHL) were conducted on 9 June 2020. No date range filters were set but the search was limited to studies involving human participants and written in English. Due to the small number of systematic reviews identified, the search was expanded to include lower levels of evidence [28]. Nevertheless, observational descriptive studies, case series and case reports were excluded, as were nonsystematic literature reviews. The full search strategy is available in Appendix S1.

Table 1 The aggregated quality indicator originating, amongst others, from the preliminary scoping review

QI-B.6.2. A patient with suspected pelvic fracture has a pelvic circumferential compression device (PCCD) applied. (Process Effectiveness)

\section{Study selection}

One author (RP) carried out the literature search, screened the results by title and abstracts using Covidence (Covidence, Melbourne VIC, Australia), and performed full-text review of shortlisted articles based on pre-defined inclusion criteria. The pre-defined inclusion criteria were based on the following population, intervention, comparison, outcome, context, study design (PICOCS) criteria:

- Population: Trauma patients with suspected or confirmed pelvic fracture(s)

- Intervention: Application of a PCCD

- Comparison: No intervention (or wrapping sheet)

- Outcomes: Clinical endpoints and/or adverse effects

- Context: Emergency trauma care

- Study designs: Systematic review, experimental and quasi-experimental studies, and observational analytical studies.

\section{Quality appraisal}

Following the search, studies selected for retrieval were assessed for internal validity using applicable JBI critical appraisal checklists [27]. This risk-of-bias assessment was performed by one author (RP). The quality threshold scores on respective checklists was 7 out of 11 for systematic reviews, 8 out of 13 for randomized control trials, 6 out of 9 for quasi-experimental studies and 7 out of 11 for cohort studies. These scores equated to a minimum quality threshold of $60 \%$ which was deemed to indicate sufficient quality for the research to be included in the review.

\section{Data extraction and synthesis}

Data were extracted by one author (RP) and verified by another (RM) using a standardized extraction template created a priori in Microsoft Excel for Mac 2019 (Microsoft Corp., Richmond, WA, USA). For systematic reviews, the following data were extracted: author(s), year of publication, number of studies included their designs, whether meta-analysis was performed and key findings. For primary research studies, following data were extracted: author(s), year of publication, study objectives and design, number of participants, participant characteristics, device(s), and key findings. Each systematic review and primary study was assigned a level of evidence in accordance with JBI [28].

\section{Results}

Search and critical appraisal results

A total of 1194 potentially relevant records were identified through database searching (Fig. 1). Following the removal of 38 duplicates, 1156 records were retrieved for title and abstract screening. This found 1108 records 


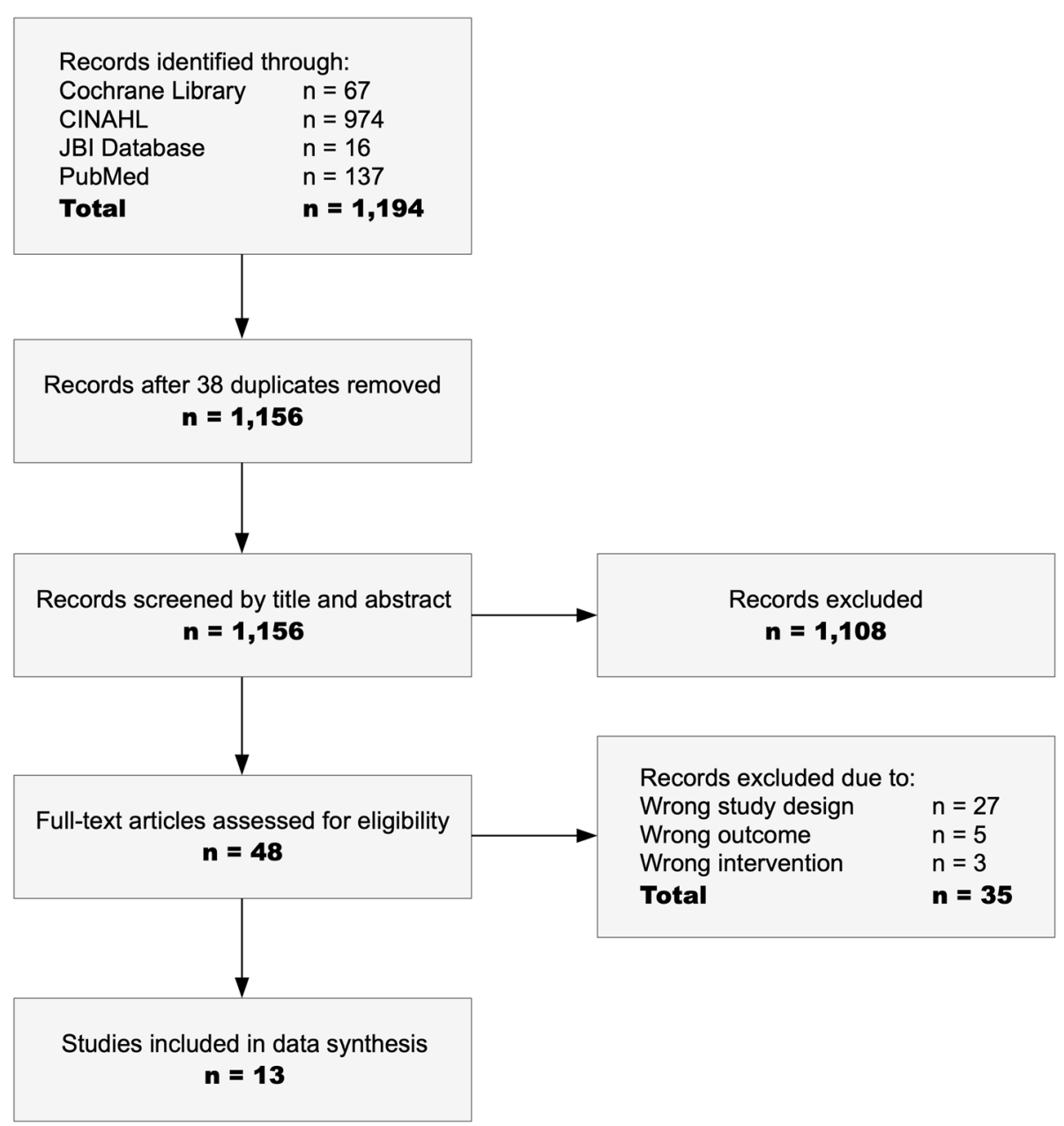

Fig. 1 PRISMA flow chart of study inclusion

to be incongruent with the inclusion criteria which were thus excluded and left 48 articles for full-text screening. Subsequently, 35 articles were excluded based on incompatibility with the review criteria which resulted in 13 articles being included for analysis in this rapid review. The 13 articles were critically appraised for methodological quality using applicable JBI critical appraisal tools. Based on the a priori minimum scores, all studies were included in this review.

\section{Description of the studies and characteristics of the evidence}

Three systematic reviews [29-31], one randomized clinical trial (crossover design) [32], two before-after studies $[33,34]$, and seven retrospective cohort studies [35-41] were included (Tables 2 and 3). For systematic reviews, the level of evidence was assigned with consideration of included studies which addressed physiological effects and clinical outcomes such as reducing bleeding and decreasing mortality. Similar to the hierarchical rating of outcomes according to importance performed in the Grading of Recommendations Assessment, Development and Evaluation (GRADE) approach [42], these outcomes were considered most critical and thus given priority over other, less important outcome measures such as biomechanical effects in determining evidence level.

\section{Summary of the evidence and clinical bottom line}

Tables 2 and 3 provide summaries of the included studies' findings. Generally, the evidence in support of the application of a PCCD in a patient with suspected or confirmed pelvic fracture is weak. Whilst three systematic reviews were identified, the design of included studies (mostly observational) in these reviews lowered their level of evidence. None of the systematic reviews included a meta-analysis of included studies. Bakhshayesh, et al. (2016) [29] explicitly stated that it was not possible to combine results due to heterogeneity amongst included studies. This heterogeneity is echoed in the primary clinical studies identified in this rapid review 
Table 2 Summary of included systematic reviews

\begin{tabular}{|c|c|c|c|c|c|c|c|}
\hline Author & $\begin{array}{l}\text { Year of } \\
\text { Publication }\end{array}$ & $\begin{array}{l}\text { Number of } \\
\text { studies } \\
\text { included }\end{array}$ & Study designs & $\begin{array}{l}\text { Total number } \\
\text { of patients/ } \\
\text { participants/ } \\
\text { cases }\end{array}$ & $\begin{array}{l}\text { Meta- } \\
\text { analysis } \\
\text { performed }\end{array}$ & Summary & $\operatorname{LOE}^{a}$ \\
\hline $\begin{array}{l}\text { Bakhshayesh, } \\
\text { et al. [29] }\end{array}$ & 2016 & 16 & $\begin{array}{l}\text { One RCT, two before-after } \\
\text { studies, four retrospective } \\
\text { cohort studies and nine } \\
\text { case series (including six } \\
\text { cadaver studies) }\end{array}$ & 1377 & No & $\begin{array}{l}\text { Included studies suggest that } \\
\text { PCCDs are effective in reducing } \\
\text { a pelvic ring fracture. PCCDs } \\
\text { may contribute to favourable } \\
\text { physiological effects during the } \\
\text { early phase of resuscitation. } \\
\text { However, study results are } \\
\text { inconclusive and conflicting } \\
\text { with regards to other outcome } \\
\text { measures, i.e. mortality, hospital } \\
\text { length of stay, and intensive care } \\
\text { unit (ICU) length of stay. Almost } \\
\text { all types of PCCDs may potentially } \\
\text { cause pressure ulcers if used for } \\
\text { extensive periods due to inevitable } \\
\text { tension over bony prominences. }\end{array}$ & 2 \\
\hline Cullinane, et al. [30] & 2011 & 6 & $\begin{array}{l}\text { One before-after study, two } \\
\text { retrospective cohort studies, } \\
\text { three case series (including } \\
\text { two cadaver studies) }\end{array}$ & 460 & No & $\begin{array}{l}\text { This systematic review was } \\
\text { conducted for the development } \\
\text { of clinical guidelines for surgical } \\
\text { and non-surgical management } \\
\text { of haemorrhage in pelvic fractures. } \\
\text { Those studies which were included } \\
\text { to evaluate the role of non-invasive } \\
\text { temporary external fixation devices } \\
\text { suggest that temporary binders } \\
\text { reduce pelvic volume and may } \\
\text { improve biomechanical stability. } \\
\text { The effectiveness of non-invasive } \\
\text { temporary external fixation devices } \\
\text { limiting haemorrhage is unclear. } \\
\text { They do not seem to affect } \\
\text { mortality. Pelvic binders may cause } \\
\text { tissue trauma due to shearing } \\
\text { forces during the application } \\
\text { process and skin breakdown over } \\
\text { bony prominences when used } \\
\text { over prolonged periods. }\end{array}$ & 3 \\
\hline $\begin{array}{l}\text { Spanjersberg, } \\
\text { et al. [31] }\end{array}$ & 2009 & 17 & $\begin{array}{l}\text { One before-after study, one } \\
\text { retrospective cohort study, } \\
\text { five case series (including } \\
\text { three cadaver studies), } \\
\text { seven case reports, three } \\
\text { opinions }\end{array}$ & 250 & No & $\begin{array}{l}\text { The reviewers concluded that } \\
\text { available studies suggest that } \\
\text { PCCDs may facilitate reduction } \\
\text { of fractures and associated } \\
\text { haemorrhage. However, data } \\
\text { concerning mortality is lacking. } \\
\text { Although the literature suggests } \\
\text { no life-threatening complications } \\
\text { occur with the use of PCCDs, } \\
\text { the nature, severity and rates of } \\
\text { complications is not fully known. } \\
\text { Most obvious is a certain risk of } \\
\text { damage to skin and potential } \\
\text { iatrogenic injury to internal organs. }\end{array}$ & 3 \\
\hline
\end{tabular}

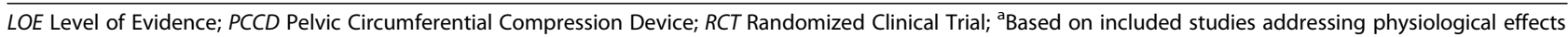

making synthesis of results challenging. Furthermore, the limited clinical research is comprised predominantly of historical cohort studies, which induces inherent and considerable risk of bias.

Included studies which address the biomechanical effects of PCCDs indicate the devices facilitate a reduction in pelvic volume and improvement in biomechanical stability [29-31, 33, 34]. Of the included studies, several suggest that PCCDs, especially if applied early, may contribute to a variety of desirable physiological effects [29$31,33,37,38,40]$. Yet, results concerning other, more critical outcome measures such as mortality and hospital or intensive care unit length of stay are ambivalent or conflicting [29-31, 35-37, 39, 41]. Three studies included sheet wrapping as an improvised method to stabilize the pelvic ring $[38,39,41]$. However, only one 
Table 3 Summary of included primary clinical studies

\begin{tabular}{|c|c|c|c|c|c|c|c|c|}
\hline Author & $\begin{array}{l}\text { Year of } \\
\text { publication }\end{array}$ & Study Design & $\begin{array}{l}\text { Pertinent } \\
\text { Objective(s) }\end{array}$ & $\begin{array}{l}\text { Number of } \\
\text { patients/ } \\
\text { participants }\end{array}$ & $\begin{array}{l}\text { Patients/participants } \\
\text { and groups }\end{array}$ & $\begin{array}{l}\text { Device(s)/ } \\
\text { Intervention(s) }\end{array}$ & Results summary & LO \\
\hline $\begin{array}{l}\text { Schweigkofler, } \\
\text { et al. [35] }\end{array}$ & 2019 & $\begin{array}{l}\text { Retrospective } \\
\text { Cohort study }\end{array}$ & $\begin{array}{l}\text { To evaluate the } \\
\text { effects of early } \\
\text { (prehospital) } \\
\text { application of a } \\
\text { PCCD on } \\
\text { transfusion } \\
\text { requirements and } \\
\text { mortality. }\end{array}$ & 64 & $\begin{array}{l}\text { Trauma patients with } \\
\text { Tile B }(n=31 ; 48.4 \%) \\
\text { and Tile C }(n=33 ; \\
51.6 \%) \text { unstable } \\
\text { pelvic fractures. A } \\
\text { PCCD was applied } \\
\text { prehospitally in } 37 \\
\text { patients (58\%); } 27 \\
(42 \%) \text { received no } \\
\text { prehospital pelvic } \\
\text { binding. }\end{array}$ & $\begin{array}{l}\text { Unspecified } \\
\text { PCCD }\end{array}$ & $\begin{array}{l}\text { There were higher } \\
\text { ISS scores ( } 29.7 \text { vs } \\
24.2 \text { ) and lower } \\
\text { probability of } \\
\text { survival (RISC-II } \\
\text { Prognosis } 81 \% \text { vs } \\
89 \% \text { ) in patient who } \\
\text { had a PCCD applied, } \\
\text { however this was } \\
\text { not statistically } \\
\text { significant. There } \\
\text { was also higher risk } \\
\text { for massive } \\
\text { transfusion (TASH- } \\
\text { Scores } 10 \% \text { vs } 6 \% \text { ) } \\
\text { and average number } \\
\text { of PRBC units } \\
\text { transfused ( } 10.5 \text { vs } \\
7.5 \text { ) in patient with } \\
\text { PCCD, again without } \\
\text { statistical } \\
\text { significance though. } \\
\text { There was no } \\
\text { statistically } \\
\text { significance } \\
\text { difference in } \\
\text { mortality ( } 20 \% \text { vs } \\
13.3 \% \text { respectively). }\end{array}$ & 3 \\
\hline Agri, et al. [36] & 2017 & $\begin{array}{l}\text { Retrospective } \\
\text { Cohort study }\end{array}$ & $\begin{array}{l}\text { To describe the } \\
\text { correlation between } \\
\text { pelvic binders and } \\
\text { patient outcomes. }\end{array}$ & 228 & $\begin{array}{l}\text { Adult (> 16 years) } \\
\text { trauma patient with } \\
\text { Tile A }(n=52 ; 22.8 \%) \text {, } \\
\text { Tile B }(n=71 ; 31.1 \%) \\
\text { and Tile C }(n=105 ; \\
46.1 \%) \text { pelvic } \\
\text { fractures. Pelvic } \\
\text { binders had been } \\
\text { applied to in the } \\
\text { field to } 144 \text { patients } \\
\text { (63\%) with } \\
\text { comparable } \\
\text { frequency among } \\
\text { the three main } \\
\text { fracture types ( } p= \\
0.61) \text {. }\end{array}$ & $\begin{array}{l}\text { Unspecified } \\
\text { PCCD (and } \\
\text { AAE) }\end{array}$ & $\begin{array}{l}\text { Tile C fractures were } \\
\text { associated with } \\
\text { higher transfusion } \\
\text { requirements ( } p< \\
0.0001 \text { ) and higher } \\
\text { mortality ( } p<0.001 \text { ). } \\
\text { There was no } \\
\text { statistically } \\
\text { significant difference } \\
\text { in injury severity } \\
\text { between patient } \\
\text { with PCCD and } \\
\text { those without (ISS } \\
26 \text { vs } 29 ; p=0.99) \text {. } \\
\text { Pelvic binders were } \\
\text { not associated with } \\
\text { differences in PRBC } \\
\text { transfusion } \\
\text { requirements (0 vs } 2 ; \\
p=0.91) \text { or mortality } \\
\text { rates at } 48 \mathrm{~h}(23 \% \text { vs } \\
18 \% ; p=0.5 \text { ) or } 30 \\
\text { days ( } 25 \% \text { vs } 11 \% ; \\
p=0.51) \text { compared } \\
\text { to the absence of } \\
\text { pelvic binders. There } \\
\text { were also no } \\
\text { statistically } \\
\text { significant } \\
\text { differences in SBP, } \\
\text { HR, SI, lactate level, } \\
\text { SBD or need for } \\
\text { AAE. No differences } \\
\text { were detected in } \\
\text { any of these } \\
\text { variables even when } \\
\text { selecting unstable } \\
\text { fracture types (B1, B3 }\end{array}$ & 3 \\
\hline
\end{tabular}


Table 3 Summary of included primary clinical studies (Continued)

\begin{tabular}{|c|c|c|c|c|c|c|c|c|}
\hline Author & $\begin{array}{l}\text { Year of } \\
\text { publication }\end{array}$ & Study Design & $\begin{array}{l}\text { Pertinent } \\
\text { Objective(s) }\end{array}$ & $\begin{array}{l}\text { Number of } \\
\text { patients/ } \\
\text { participants }\end{array}$ & $\begin{array}{l}\text { Patients/participants } \\
\text { and groups }\end{array}$ & $\begin{array}{l}\text { Device(s)/ } \\
\text { Intervention(s) }\end{array}$ & Results summary & LOE \\
\hline & & & & & & & and C) only. & \\
\hline Hsu, et al. [37] & 2017 & $\begin{array}{l}\text { Retrospective } \\
\text { Cohort study }\end{array}$ & $\begin{array}{l}\text { To compare the } \\
\text { effects of early } \\
\text { pelvic binding } \\
\text { (based on suspicion } \\
\text { of pelvic injury) } \\
\text { with late pelvic } \\
\text { binding (after } \\
\text { fracture } \\
\text { confirmation by } \\
\text { radiography) }\end{array}$ & 204 & $\begin{array}{l}\text { Trauma patients with } \\
\text { a loss of } \\
\text { consciousness or } \\
\text { GCS }<13, \text { SBP }<90 \\
\text { mmHg, fall from } \geq 6 \\
\text { m; injury to multiple } \\
\text { vital organs, and } \\
\text { suspected pelvic } \\
\text { injury. Pelvic binders } \\
\text { had been applied to } \\
56 \text { ( } 27.5 \%) \text { patients } \\
\text { after confirmation of } \\
\text { pelvic fracture and } \\
148 \text { ( } 72.5 \%) \text { patients } \\
\text { with suspected } \\
\text { pelvic injury. }\end{array}$ & $\begin{array}{l}\text { SAM Pelvic } \\
\text { Sling }{ }^{\oplus} \|\end{array}$ & $\begin{array}{l}\text { There were no } \\
\text { statistically } \\
\text { significant } \\
\text { differences in } \\
\text { hospital LOS, ICU } \\
\text { LOS, RTS, ISS score; } \\
\text { percentage of SBP } \\
<90 \text { mmHg, GCS, } \\
\text { percentage of AIS } \\
\leq 3 \text {, angiography for } \\
\text { AAE or mortality. } \\
\text { However, those } \\
\text { patients who } \\
\text { received early pelvic } \\
\text { binding had } \\
\text { significantly less } \\
\text { blood transfusion } \\
\text { requirements ( } 2462 \\
\text { ml vs } 4385 \text { ml; } p= \\
0.009 \text { ). Furthermore, } \\
\text { uni- and multivariant } \\
\text { regression analysis } \\
\text { to adjust for } \\
\text { confounders } \\
\text { revealed significantly } \\
\text { reduced mortality } \\
\text { rates associated with } \\
\text { early binding ( } p= \\
0.030 \text { and } p=0.039 \\
\text { respectively). }\end{array}$ & 3 \\
\hline Fu, et al. [38] & 2013 & $\begin{array}{l}\text { Retrospective } \\
\text { Cohort study }\end{array}$ & $\begin{array}{l}\text { To evaluate the } \\
\text { effects of PCCDs in } \\
\text { patients with pelvic } \\
\text { fractures who } \\
\text { required transfer to } \\
\text { trauma centres. }\end{array}$ & 585 & $\begin{array}{l}\text { Patients with stable } \\
(n=450 ; 76.9 \%) \text { and } \\
\text { unstable }(n=135 ; \\
23.1 \%) \text { pelvic } \\
\text { fractures who were } \\
\text { transferred to a } \\
\text { trauma centre within } \\
24 \mathrm{~h} \text {. }\end{array}$ & $\begin{array}{l}\text { Unspecified } \\
\text { PCCD or } \\
\text { sheet } \\
\text { wrapping }\end{array}$ & $\begin{array}{l}\text { The patients with } \\
\text { stable pelvic fracture } \\
\text { who received } \\
\text { pretransfer PCCDs } \\
\text { ( } n=62 ; 13.8 \%) \\
\text { required significantly } \\
\text { fewer blood } \\
\text { transfusions (120.2 } \\
\text { ml vs } 231.8 \mathrm{~mL} ; p= \\
0.018) \text {, had shorter } \\
\text { intensive care unit } \\
\text { LOS (1.7 days vs } 3.4 \\
\text { days; } p=0.029) \text { and } \\
\text { shorter hospital LOS } \\
\text { (6.8 days vs } 10.4 \\
\text { days; } p=0.018) \\
\text { compared with } \\
\text { patients who did } \\
\text { not receive the } \\
\text { pretransfer PCCD. } \\
\text { The patients with } \\
\text { unstable pelvic } \\
\text { fractures who } \\
\text { received pretransfer } \\
\text { PCCDs ( } n=91 ; \\
67.4 \%) \text { also required } \\
\text { significantly fewer } \\
\text { blood transfusions } \\
(398.4 \text { ml vs } 1954.5 \\
\text { ml; } p<0.001 \text { ), } \\
\text { shorter intensive } \\
\text { care unit LOS (6.6 } \\
\text { days vs } 11.8 \text { days; } \\
p=0.024) \text { and }\end{array}$ & 3 \\
\hline
\end{tabular}


Table 3 Summary of included primary clinical studies (Continued)

\begin{tabular}{|c|c|c|c|c|c|c|c|c|}
\hline Author & $\begin{array}{l}\text { Year of } \\
\text { publication }\end{array}$ & Study Design & $\begin{array}{l}\text { Pertinent } \\
\text { Objective(s) }\end{array}$ & $\begin{array}{l}\text { Number of } \\
\text { patients/ } \\
\text { participants }\end{array}$ & $\begin{array}{l}\text { Patients/participants } \\
\text { and groups }\end{array}$ & $\begin{array}{l}\text { Device(s)/ } \\
\text { Intervention(s) }\end{array}$ & Results summary & 0 \\
\hline & & & & & & & $\begin{array}{l}\text { shorter hospital LOS } \\
\text { ( } 9.4 \text { days vs } 19.5 \\
\text { days; } p=0.006 \text { ) } \\
\text { compared with } \\
\text { patients who did } \\
\text { not receive the } \\
\text { pretransfer PCCD. }\end{array}$ & \\
\hline Pizanis, et al. [39] & 2013 & $\begin{array}{l}\text { Retrospective } \\
\text { Cohort study }\end{array}$ & $\begin{array}{l}\text { To compare } \\
\text { transfusion } \\
\text { requirements of } \\
\text { PRBC, LOS, mortality } \\
\text { and incidence of } \\
\text { lethal pelvic } \\
\text { bleeding between } \\
\text { patients which } \\
\text { were treated by } \\
\text { circumferential } \\
\text { sheets, binders and } \\
\text { c-clamps. }\end{array}$ & 192 & $\begin{array}{l}\text { Trauma patients with } \\
\text { fractures or } \\
\text { disruptions of the } \\
\text { pelvic ring. (The } \\
\text { median age of } \\
\text { patients treated with } \\
\text { binders was } \\
\text { significantly lower } \\
\text { than in those treated } \\
\text { with sheets of c- } \\
\text { clamps.) One- } \\
\text { hundred-and-thirty- } \\
\text { three patients (69\%) } \\
\text { were treated with c- } \\
\text { clamp, } 31 \text { (16\%) with } \\
\text { sheets and } 28 \text { (15\%) } \\
\text { with binders. }\end{array}$ & $\begin{array}{l}\text { Unspecified } \\
\text { PCCDs, sheet } \\
\text { wrapping and } \\
\text { c-clamp }\end{array}$ & $\begin{array}{l}\text { There were no } \\
\text { statistically } \\
\text { significant } \\
\text { differences in PRBC } \\
\text { requirements ( } p= \\
0.26), \text { LOS }(p=0.20) \\
\text { or mortality }(p= \\
0.08) \text {. However, } \\
\text { wrapping sheets } \\
\text { were associated with } \\
\text { a significantly higher } \\
\text { incidence of lethal } \\
\text { bleeding compared } \\
\text { to PCCD and c- } \\
\text { clamp }(23 \% \text { vs } 4 \% \text { vs } \\
8 \% ; p=0.02) .\end{array}$ & 3 \\
\hline Knops, et al. [32] & 2011 & $\begin{array}{l}\text { Randomized } \\
\text { controlled } \\
\text { trial }\end{array}$ & $\begin{array}{l}\text { To quantify the } \\
\text { pressure at the } \\
\text { region of the } \\
\text { greater trochanters } \\
\text { and the sacrum, } \\
\text { induced by PCCDs } \\
\text { in healthy } \\
\text { individuals. }\end{array}$ & 80 & $\begin{array}{l}\text { Healthy individuals } \\
\text { lying on a spine } \\
\text { board and lying on a } \\
\text { hospital bed. }\end{array}$ & $\begin{array}{l}\text { Pelvic Binder }{ }^{\oplus}, \\
\text { SAM-Sling }^{\circledast} \\
\text { and T-POD }\end{array}$ & $\begin{array}{l}\text { Whilst lying on a } \\
\text { spine board, the } \\
\text { maximum pressure } \\
\text { on the skin at the } \\
\text { area of the greater } \\
\text { trochanter exceeded } \\
9.3 \mathrm{kPa} \text { (tissue } \\
\text { damage threshold) } \\
\text { with all three } \\
\text { devices. No } \\
\text { correlations of } \\
\text { maximum pressure } \\
\text { with BMl, waist size, } \\
\text { or age on a spine } \\
\text { board at the area of } \\
\text { the greater } \\
\text { trochanter were } \\
\text { observed, except } \\
\text { with an increase in } \\
\text { maximum pressure } \\
\text { with age ( } p=0.031 \text { ) } \\
\text { when using one of } \\
\text { the devices (SAM- } \\
\text { Sling }{ }^{\oplus} \text {. Whilst lying } \\
\text { on the hospital bed, } \\
\text { considerable } \\
\text { reductions in } \\
\text { maximum pressure, } \\
\text { were found with all } \\
\text { devices, in most } \\
\text { cases below } 9.3 \mathrm{kPa} \text {. }\end{array}$ & 1 \\
\hline Tan, at al [33]. & 2010 & $\begin{array}{l}\text { Before-after } \\
\text { study }\end{array}$ & $\begin{array}{l}\text { To measure the } \\
\text { immediate } \\
\text { biomechanical and } \\
\text { hemodynamic } \\
\text { effects of pelvic } \\
\text { binding. }\end{array}$ & 15 & $\begin{array}{l}\text { Patients with } \\
\text { unstable pelvic } \\
\text { fractures who } \\
\text { presented to the } \\
\text { emergency } \\
\text { department and } \\
\text { who did not receive } \\
\text { prehospital pelvic } \\
\text { binding. }\end{array}$ & $\mathrm{T}^{-P O D^{\oplus}}$ & $\begin{array}{l}\text { Application of the } \\
\text { PCCD reduced pubic } \\
\text { symphyseal diastasis } \\
\text { by } 60 \% \text { (range } 24- \\
92 \%, p=0.01 \text { ). Mean } \\
\text { values of mean } \\
\text { arterial pressures } \\
\text { increased } \\
\text { significantly from } \\
64.7 \text { to } 81.2 \mathrm{mmHg}\end{array}$ & 2 \\
\hline
\end{tabular}


Table 3 Summary of included primary clinical studies (Continued)

\begin{tabular}{|c|c|c|c|c|c|c|c|c|}
\hline Author & $\begin{array}{l}\text { Year of } \\
\text { publication }\end{array}$ & Study Design & $\begin{array}{l}\text { Pertinent } \\
\text { Objective(s) }\end{array}$ & $\begin{array}{l}\text { Number of } \\
\text { patients/ } \\
\text { participants }\end{array}$ & $\begin{array}{l}\text { Patients/participants } \\
\text { and groups }\end{array}$ & $\begin{array}{l}\text { Device(s)/ } \\
\text { Intervention(s) }\end{array}$ & Results summary & $\overline{L O E}$ \\
\hline & & & & & & & $\begin{array}{l}(p=0.04) \text {. Similarly, } \\
\text { heart rates } \\
\text { decreased } \\
\text { significantly from } \\
106 \text { to } 93 \text { beats per } \\
\text { minute }(p=0.04) \text {. }\end{array}$ & \\
\hline Croce, et al. [40] & 2007 & $\begin{array}{l}\text { Retrospective } \\
\text { Cohort study }\end{array}$ & $\begin{array}{l}\text { To compare the } \\
\text { efficacy of pelvic } \\
\text { binding to EPF. }\end{array}$ & 186 & $\begin{array}{l}\text { Trauma patients with } \\
\text { fractures or } \\
\text { disruptions of the } \\
\text { pelvic ring. } \\
\text { Ninety-three patients } \\
(50 \%) \text { were treated } \\
\text { with EPF and } 93 \\
\text { (50\%) had the T-POD } \\
\text { applied. }\end{array}$ & T-POD ${ }^{\oplus}$ & $\begin{array}{l}\text { There were no } \\
\text { differences in age or } \\
\text { shock severity. Those } \\
\text { patients who had a } \\
\text { T-POD applied had } \\
\text { significantly reduced } \\
24-h \text { (4.9 U vs } 17.1 \text { U; } \\
p<0.0001) \text { and } 48-h \\
\text { transfusions (6.0 U vs } \\
18.6 \text { U; } p<0.0001) \text {. } \\
\text { Compared to EPF, } \\
\text { the T-POD also facili- } \\
\text { tated significantly } \\
\text { decreased hospital } \\
\text { LOS ( } 16.5 \text { days vs } \\
24.4 \text { days; } p<0.03) \text {. } \\
\text { There was reduced } \\
\text { mortality with the T- } \\
\text { POD, however, this } \\
\text { was not statistically } \\
\text { significant (26\% vs } \\
37 \% ; p=0.11) .\end{array}$ & 3 \\
\hline $\begin{array}{l}\text { Ghaemmaghami, } \\
\text { et al. [41] }\end{array}$ & 2007 & $\begin{array}{l}\text { Retrospective } \\
\text { Cohort study }\end{array}$ & $\begin{array}{l}\text { To assess the } \\
\text { effectiveness of } \\
\text { early application of } \\
\text { a PCCD when } \\
\text { compared to no } \\
\text { device. }\end{array}$ & 236 & $\begin{array}{l}\text { Patients with pelvic } \\
\text { fractures and at least } \\
\text { one of the following } \\
\text { risk factors: } \\
\text { - unstable fracture } \\
\text { - age }>55 \text { years } \\
\text { - hypotension } \\
\text { One-hundred-and- } \\
\text { eighteen patients } \\
(50 \%) \text { were treated } \\
\text { with the PCCD and } \\
118(50 \%) \text { did not } \\
\text { receive any } \\
\text { standardized pelvic } \\
\text { binding other than } \\
\text { occasional sheet } \\
\text { wrapping. }\end{array}$ & $\begin{array}{l}\text { Unspecified } \\
\text { PCCD }\end{array}$ & $\begin{array}{l}\text { The two groups had } \\
\text { similar fracture } \\
\text { patterns, age, and } \\
\text { injury severity. In the } \\
\text { comparison of } \\
\text { patients wo were } \\
\text { treated with a PCCD } \\
\text { with those who } \\
\text { received no } \\
\text { standardized pelvic } \\
\text { binding, there were } \\
\text { no significant } \\
\text { differences in } \\
\text { mortality (23\% vs } \\
23 \% ; p=0.92) \text {, need } \\
\text { for AAE }(11 \% \text { vs } \\
15 \% ; p=0.35) \text {, or } 24- \\
\text { h transfusion (5.2U } \\
\text { vs } 4.6 \mathrm{U} ; p=0.64) \text {. }\end{array}$ & 3 \\
\hline Krieg, et al. [34] & 2005 & $\begin{array}{l}\text { Before-after } \\
\text { study }\end{array}$ & $\begin{array}{l}\text { To assess the } \\
\text { effectiveness of a } \\
\text { PCCD in reducing } \\
\text { and stabilizing } \\
\text { pelvic ring fractures. }\end{array}$ & 13 & $\begin{array}{l}\text { Adult patients (> } 16 \\
\text { years) with partially } \\
\text { stable or unstable } \\
\text { pelvic fractures with } \\
\text { external or internal } \\
\text { rotation pattern. }\end{array}$ & $\begin{array}{l}\text { Unspecified } \\
\text { PCCD }\end{array}$ & $\begin{array}{l}\text { In patients with } \\
\text { external rotation, the } \\
\text { PCCD significantly } \\
\text { reduced the pelvic } \\
\text { width by } 9.9 \pm 6.0 \% \text {. } \\
\text { In patient with } \\
\text { internal rotation, } \\
\text { there was no } \\
\text { significant over- } \\
\text { pressurization due to } \\
\text { application of the } \\
\text { PCCD. }\end{array}$ & 2 \\
\hline
\end{tabular}

AAE Arterial Angio-Embolization; AIS Abbreviate Injury Score; BMI Body Mass Index; EPF External Pelvic Fixation; GCS Glasgow Coma Score; HR Heart Rate; ICU Intensive Care Unit; ISS Injury Severity Scale; LOE Level of Evidence; LOS Length of Stay; PCCD Pelvic Circumferential Compression Device; PRBC Packed Red Blood Cells; RISC Revised Injury Severity Classification; RTS Revised Trauma Score; SBD Standard Base Deficit; SBP Systolic Blood Pressure; SI Shock Index; TASH Trauma Associated Severe Haemorrhage 
of these (Pizanis, at al. 2013) [39] compared this method to the application of a commercial PCCD and demonstrated benefits in using a PCCD over improvised pelvic binding in reducing mortality. The systemic reviews consistently report on potential adverse effects of PCCDs. These including mostly skin damage, myonecrosis and peroneal nerve palsy when used for extended periods of time, but also injury to internal organs as a result of shearing forces during the application process [29-31].

The clinical bottom line is that there is no high-level evidence that the application of a PCCD reduces haemorrhage or mortality in suspected or confirmed pelvic fractures. The best available evidence suggests that a PCCD provides temporary pelvic ring stabilization and can serve as an adjunct to early haemorrhage control. The application of PCCD carries a certain potential for iatrogenic harm, however, clinical benefits seem to outweigh this risk. Given the limited data to show undisputable benefit, further research on this topic is needed. In particular, there is a lack of research in the prehospital arena as well as studies which examine the effectiveness and safety of PCCDs in specific pelvic fractures types according to Young-Burgess classification as this mechanistic classification is more practical for the prehospital context.

\section{Discussion}

Patients suffering pelvic fractures are at risk of severe and potentially life-threatening bleeding [43, 44]. Especially patients with unstable pelvic fracture types are at high risk of exsanguinating haemorrhage $[45,46]$. Palpation of the pelvis is unreliable in detecting instability and has been associated with dislodging clots and initiating further blood loss [47]. Therefore, in early major trauma care, the presence of pelvic disruption should be based on suspicion after consideration of the mechanism of injury rather than confirmation by physical examination. PCCDs have been shown to provide effective biomechanical reduction in partially stable and unstable pelvic fractures [48]. A clinically reasonable assumption is that the prompt application of a PCCD facilitates early stabilization of unstable fractures and thus leads to favourable physiological effects and ultimately desirable patient outcomes. This rapid review aimed to summarize current evidence for the effectiveness and safety of noninvasive PCCDs and identified several, albeit methodologically weak studies in support of the intervention. As such, this rapid review was unable to identify highquality evidence and the best available evidence should be combined with expert consensus in a process such as RAM to assess the validity of the QI under discussion.

Health care quality measurement and improvement are complex endeavours. Considering the resources health care organizations invest in them and the potential adverse consequences if conducted poorly [49, 50], it is important to get it right from the start. Unfortunately, indicators are often chosen because the required data is easily attainable rather than because they are evidence-based [51]. When indicators are developed or transferred between health care systems, it is critical to review their supporting evidence and the quality thereof $[52,53]$. A QI is preferably based on high-quality evidence clearly demonstrating that the desirable effects outweigh the undesirable effects. Such evidence is produced by large, thoroughly conducted RCTs that demonstrate consistent impressive benefits with limited adverse effects and minimal cost. In the absence of such high-quality evidence, best available evidence should be combined with expert consensus to assess the validity of the indicator. Therein lies the essence of a quality indicator and what distinguishes it from a performance indicator - a QI has scientific credibility, i.e. there is evidence and/or expert consensus that the indicator can be used to make a judgement about quality [17]. Not only are health care quality improvement managers increasingly required to deploy such scientific methods to develop measures of quality, but also they are required to do so in limited amounts of time [54]. This presents a potential misalignment between QI development and timelines set by organizational quality improvement needs $[55,56]$. This paper presents an example of a fasttracked systematic literature review methodology which balanced its scope against time and resource constraints, and in doing so may prevent protraction and provide a timely evidence summary to inform QI development. From inception to completion this rapid review took approximately 3 months; a relatively short timeframe compared to full systematic reviews which commonly take 12 to 24 months to complete $[57,58]$.

There are several significant limitations that the omission or simplification of systematic review methods induce. The search strategy was limited by restricting the number of databases consulted, excluding all nonEnglish language papers, using more specific search terms and excluding lower levels of evidence. Databases were restricted in line with guidance for rapid reviews and evidence summaries by JBI. Whilst systematic reviewer and meta-analysts should conduct exhaustive searches in multiple databases, rapid reviews commonly omit several databases to focus on those expected to yield best results. This approach is justifiable by studies which have demonstrated only marginal improvement in relevant results by increasing the number of databases searched $[59,60]$. The search for studies in rigorously conducted systematic reviews should not be restricted by language. Limiting results to those written in English inevitable introduces English language bias or Tower of Babel bias potentially leading to an over- or 
underestimation of an intervention's effectiveness [61]. Reliable translation services, however, require time and financial resources making them a less suitable part of a rapid review search strategy. Optimal search strategies aim for maximum number of relevant references with minimal noise, i.e. best sensitivity and specificity. In this balance, rapid reviews commonly lean towards specificity. The search terms in this rapid review were more specific by using narrower MeSH terms (e.g. $\mathrm{MH}$ "pelvic fractures"), using Boolean operators to narrow MeSH headings (e.g. (pelvic bones [mh] OR pelvis [mh]) AND (fractures, bone $[\mathrm{mh}]$ OR wounds and injuries $[\mathrm{mh}]$ ) and by avoiding less common keywords (e.g. splint). JBI evidence summaries are ideally based on several systematic reviews, however, when no systematic reviews are identified, lower levels of evidence are included [27]. This rapid review adopted the approach but leaned towards more comprehensive inclusion by lowering the methodological exclusion threshold to observational descriptive studies. Whilst data extraction was verified by a second reviewer, the preceding study selection and quality appraisal was performed by only one reviewer. Expediting the review process in this way is frequently done in rapid reviews, however, introduces considerable risk of bias and error.

\section{Conclusion}

This study provides an example of how the timely knowledge synthesis through the deployment of a streamlined rapid review approach can inform QI development. More specifically, the study has reviewed best available evidence regarding the application of a PCCD in patients with suspected pelvic fractures and summarized this into a synopsis for feasible consideration by an expert panel tasked to assess the validity of a related QI. The process of applying a PCCD is not clearly linked to desirable clinical outcomes and does carry a potential for iatrogenic harm. Nevertheless, the clinical benefits seem to outweigh risks. This best available evidence is of low quality strengthening the need for its perusal by an expert panel before possible QI implementation.

\section{Supplementary information}

Supplementary information accompanies this paper at https://doi.org/10. 1186/s13049-020-00762-5.

\section{Additional file 1.}

\section{Abbreviations}

AAE: Arterial Angio-Embolization; AIS: Abbreviate Injury Score; BMI: Body Mass Index; CINAHL: Cumulative Index to Nursing and Allied Health Literature; EPF: External Pelvic Fixation; GCS: Glasgow Coma Score; GRADE: Grading of Recommendations Assessment, Development and Evaluation; HR: Heart Rate; ICU: Intensive Care Unit; ISS: Injury Severity Scale; JBI: Joanna Briggs Institute; LOE: Level of Evidence; LOS: Length of Stay; PCCD: Pelvic Circumferential Compression Device; PICOCS: Population,
Intervention, Comparison, Outcome, Context, Study design; QI: Quality Indicator; RAM: RAND/UCLA Appropriateness Method; RCT: Randomized Controlled Trial; RISC: Revised Injury Severity Classification; RTS: Revised Trauma Score; SBD: Standard Base Deficit; SBP: Systolic Blood Pressure; SI: Shock Index; TASH: Trauma Associated Severe Haemorrhage; WHO: World Health Organization

\section{Acknowledgements}

The larger research project this study forms part of is supported by an Australian Government Research Training Program Scholarship.

\section{Authors' contributions}

$\mathrm{RP}$ is the guarantor. RP incepted the study. RP conducted the search and quality appraisal. RP and RM performed data extraction. All authors contributed intellectually to the manuscript approved its final version.

\section{Funding}

NA

\section{Availability of data and materials}

The datasets used and/or analysed during the current study are available from the corresponding author on reasonable request.

\section{Ethics approval and consent to participate}

The project this study forms part of has been approved by the University of Adelaide Human Research Ethics Committee (approval number H-2017-157).

\section{Consent for publication}

NA

\section{Competing interests}

The authors declare that they have no competing interests.

Received: 18 March 2020 Accepted: 3 July 2020

Published online: 13 July 2020

\section{References}

1. Pfeifer R, Teuben M, Andruszkow H, Barkatali BM, Pape HC. Mortality patterns in patients with multiple trauma: a systematic review of autopsy studies. PLoS One. 2016;11(2):1-9.

2. Ruatti S, Guillot S, Brun J, Thony F, Bouzat P, Payen JF, et al. Which pelvic ring fractures are potentially lethal? Injury. 2015;46(6):1059-63.

3. Hermans E, Biert J, van Vugt $A B$, Edwards MJR. Research on relation of mortality and hemodynamics in patients with an acute pelvic ring fracture. J Acute Dis. 2016:5(2):117-22

4. Starr AJ, Griffin DR, Reinert CM, Frawley WH, Walker J, Whitlock SN, et al. Pelvic ring disruptions: prediction of associated injuries, transfusion requirement, pelvic arteriography, complications, and mortality. J Orthop Trauma. 2002;16(8):553-61.

5. Dalal SA, Burgess AR, Siegel JH, Young JW, Brumback RJ, Poka A, et al. Pelvic fracture in multiple trauma: classification by mechanism is key to pattern of organ injury, resuscitative requirements, and outcome. J Trauma - Inj Infect Crit Care. 1989;29(7):981-1002.

6. Schmal H, Markmiller M, Mehlhorn AT, Sudkamp NP. Epidemiology and outcome of complex pelvic injury. Acta Orthop Belg. 2005;71(1):41-7.

7. Tile M. Acute pelvic fractures: II. Principles of management. J Am Acad Orthop Surg. 1996;4(3):152-61.

8. Tile M. Pelvic ring fractures: should they be fixed? J Bone Jt Surg - Ser B. 1988;70(1):1-12.

9. Young JW, Burgess AR, Brumback RJ, Poka A. Pelvic fractures: value of plain radiography in early assessment and management. Radiology. 1986;160(2): 445-51.

10. Grant PT. The diagnosis of pelvic fractures by "springing". Arch Emerg Med. 1990;7(3):178-82.

11. Lee C, Porter K. The prehospital management of pelvic fractures. Emerg Med J. 2007;24(2):130-3.

12. Sauerland S, Bouillon B, Rixen D, Raum MR, Koy T, Neugebauer EAM. The reliability of clinical examination in detecting pelvic fractures in blunt trauma patients: a meta-analysis. Arch Orthop Trauma Surg. 2004;124(2): $123-8$. 
13. National Institute for Health and Care Excellence. Major trauma: assessment and management of major trauma - NICE Guideline NG39. London; 2016. Available from: https://www.nice.org.uk/guidance/ng39/evidence/fullguideline-pdf-2308122833.

14. Campbell J, Alson R, editors. International trauma life support for emergency care providers. 8th ed. Downer Grove, IL: ITLS - International Trauma Life Support; 2015. p. 432.

15. Joint Royl Colleges Ambulance Liaison Committee and Association of Ambulance Chief Executives. JRCALC Clinical Practice Guidelines 2019 Somerset: Class Professional Publishing; 2019. p. 724.

16. Pap R, Lockwood C, Stephenson M, Simpson P. Indicators to measure prehospital care quality: a scoping review. JBI Database Syst Rev Implement Reports. 2018;16(11):2192-223.

17. Campbell SM, Braspenning J, Hutchingson A, Marshall MN. Research methods used in developing and applying quality indicators in primary care. Qual Saf Heal Care. 2002;11:358-64.

18. Lawrence M, Olesen F. Indicators of quality in health care. Eur J Gen Pract. 1997;3(9):103-8.

19. Kötter T, Blozik E, Scherer M. Methods for the guideline-based development of quality indicators - a systematic review. Implement Sci. 2012;7(1):21.

20. Hutchinson A, McIntosh A, Anderson J, Gilbert C, Field R. Developing primary care review criteria from evidence-based guidelines: coronary heart disease as a model. Br J Gen Pract. 2003:53(494):690-6.

21. Mainz J. Defining and classifying clinical indicators for quality improvement. Int J Qual Heal Care. 2003:15(156):523-30.

22. Halcomb E, Davidson P, Hardaker L. Using the consensus development conference method in healthcare research. Nurse Res. 2008;16(1):56-71.

23. Fitch K, Bernstein SJJ, Aguilar MDD, Burnand B, LaCalle JRR, Lazaro P, et al. The RAND/UCLA appropriateness method User's manual; 2001. p. 109. Available from: http://www.rand.org.

24. Tricco AC, Antony J, Zarin W, Strifler L, Ghassemi M, Ivory J, et al. A scoping review of rapid review methods. BMC Med. 2015;13(224):1-15.

25. Grant MJ, Booth A. A typology of reviews: an analysis of 14 review types and associated methodologies. Health Inf Libr J. 2009;26(2):91-108.

26. Khangura S, Konnyu K, Cushman R, Grimshaw J, Moher D. Evidence summaries : a rapid review method. Syst Rev. 2012;1(10):20146-4053.

27. Munn Z, Lockwood C, Moola S. The development and use of evidence summaries for point of care information systems: a streamlined rapid review approach. Worldviews Evidence-Based Nurs. 2015;12(3):131-8.

28. Joanna Briggs Institute. The JBI Approach. 2017. Available from: http:// joannabriggs.org/jbi-approach.html.

29. Bakhshayesh $P$, Boutefnouchet $T$, Tötterman A. Effectiveness of non invasive external pelvic compression: a systematic review of the literature. Scand J Trauma Resusc Emerg Med. 2016;24(1):1-9.

30. Cullinane DC, Schiller HJ, Zielinski MD, Bilaniuk JW, Collier BR, Como J, et al. Eastern association for the surgery of trauma practice management guidelines for hemorrhage in pelvic fracture-update and systematic review. J Trauma - Inj Infect Crit Care. 2011;71(6):1850-68.

31. Spanjersberg WR, Knops SP, Schep NWL, van Lieshout EMM, Patka P, Schipper IB. Effectiveness and complications of pelvic circumferential compression devices in patients with unstable pelvic fractures: a systematic review of literature. Injury. 2009;40(10):1031-5.

32. Knops SP, Van Lieshout EMM, Spanjersberg WR, Patka P, Schipper IB. Randomised clinical trial comparing pressure characteristics of pelvic circumferential compression devices in healthy volunteers. Injury. 2011; 42(10):1020-6

33. Tan ECTH, Van Stigt SFL, Van Vugt AB. Effect of a new pelvic stabilizer $\left(T_{-P O D}{ }^{\oplus}\right)$ on reduction of pelvic volume and haemodynamic stability in unstable pelvic fractures. Injury. 2010;41(12):1239-43.

34. Krieg JC, Mohr M, Ellis TJ, Simpson TS, Madey SM, Bottlang M. Emergent stabilization of pelvic ring injuries by controlled circumferential compression: a clinical trial. J Trauma - Inj Infect Crit Care. 2005;59(3):659-64.

35. Schweigkofler U, Wohlrath B, Trentzsch H, Horas K, Hoffmann R, Wincheringer D. Is there any benefit in the pre-hospital application of pelvic binders in patients with suspected pelvic injuries? Eur J Trauma Emerg Surg. 2019;0123456789

36. Agri F, Bourgeat M, Becce F, Moerenhout $K$, Pasquier M, Borens $O$, et al. Association of pelvic fracture patterns, pelvic binder use and arterial angioembolization with transfusion requirements and mortality rates; a 7-year retrospective cohort study. BMC Surg. 2017:17(1):1-12.
37. Der Hsu S, Chen CJ, Chou YC, Wang SH, Chan DC. Effect of early pelvic binder use in the emergency management of suspected pelvic trauma: a retrospective cohort study. Int J Environ Res Public Health. 2017; 14(10):1-9.

38. Fu CY, Wu YT, Liao CH, Kang SC, Wang SY, Hsu YP, et al. Pelvic circumferential compression devices benefit patients with pelvic fractures who need transfers. Am J Emerg Med. 2013;31(10):1432-6.

39. Pizanis A, Pohlemann T, Burkhardt M, Aghayev E, Holstein JH. Emergency stabilization of the pelvic ring: clinical comparison between three different techniques. Injury. 2013;44(12):1760-4.

40. Croce MA, Magnotti LJ, Savage SA, Wood GW, Fabian TC. Emergent pelvic fixation in patients with exsanguinating pelvic fractures. J Am Coll Surg. 2007;204(5):935-9.

41. Ghaemmaghami V, Sperry J, Gunst M, Friese R, Starr A, Frankel H, et al. Effects of early use of external pelvic compression on transfusion requirements and mortality in pelvic fractures. Am J Surg. 2007;194(6):720-3.

42. Guyatt GH, Oxman AD, Vist GE, Kunz R, Falck-Ytter Y, Schünemann HJ. GRAD $\mathrm{E}$ : what is "quality of evidence" and why is it important to clinicians? BMJ. 2008:336(2):995-8.

43. Gabbe BJ, De Steiger R, Esser M, Bucknill A, Russ MK, Cameron PA. Predictors of mortality following severe pelvic ring fracture: results of a population-based study. Injury. 2011;42(10):985-91.

44. Blackmore CC, Cummings P, Jurkovich GJ, Linnau KF, Hoffer EK, Rivara FP. Predicting major hemorrhage in patients with pelvic fracture. J Trauma - Inj Infect Crit Care. 2006;61(2):346-52.

45. Pohlemann T, Stengel D, Tosounidis G, Reilmann H, Stuby F, Stöckle U, et al. Survival trends and predictors of mortality in severe pelvic trauma: estimates from the German pelvic trauma registry initiative. Injury. 2011; 42(10):997-1002.

46. Cryer $H$, Miller F, Evers B, Rouben L, Seligson D. Pelvic fracture classification: correlation with hemorrhage. J Trauma. 1988;28(7):973-80.

47. Little G, Kelly M, Glucksman E. Critical pitfalls in the immediate assessment of the trauma patient. Trauma. 2001;3(1):43-51.

48. Knops SP, Schep NWL, Spoor CW, Van Riel MPJM, Spanjersberg WR, Kleinrensink GJ, et al. Comparison of three different pelvic circumferential compression devices: a biomechanical cadaver study. J Bone Jt Surg - Ser A. 2011;93(3):230-40

49. Shahian DM, Normand SLT, Friedberg MW, Hutter MM, Pronovost PJ. Rating the raters: the inconsistent quality of health care performance measurement. Ann Surg. 2016:264(1):36-8.

50. Chin MH, Muramatsu N. What is the quality of quality of medical care measures? Rashomon-like relativism and real-world applications. Perspect Biol Med. 2003;46(1):5-20.

51. Saver BG, Martin SA, Adler RN, Candib LM, Deligiannidis KE, Golding J, et al. Care that matters: quality measurement and health care. PLoS Med. 2015; 12(11):1-10.

52. Mainz J. Developing evidence-based clinical indicators: a state of the art methods primer. Int J Qual Heal Care. 2003;15(Supp 1):i5-11.

53. Marshall MN, Shekelle PG, McGlynn EA, Campbell S, Brook RH, Roland MO Can health care quality indicators be transferred between countries? Qual Saf Health Care. 2003:12(1):8-12.

54. Cassel C, Conway P, Delbanco S, Jha A, Saunders R, Lee T. Getting more performance from performance measurement Christine. N Engl J Med. 2014;371(23):2145-7.

55. Ganann R, Ciliska D, Thomas H. Expediting systematic reviews: methods and implications of rapid reviews; 2010. p. 1-10.

56. Nair R, Aggarwal R, Khanna D. Methods of formal consensus in classification/diagnostic criteria and guideline development. Semin Arthritis Rheum. 2011:41(2):95-105.

57. Tricco A, Langlois E, Straus S. Rapid reviews to strengthen health policy and systems: a practical guide [internet]. Genève: World Health Organisation and Alliance for Health Ploicy and Systems Research; 2017. p. 142. Available from: https://www.who.int/alliance-hpsr/resources/ publications/rapid-review-guide/en/.

58. Borah R, Brown AW, Capers PL, Kaiser KA. Analysis of the time and workers needed to conduct systematic reviews of medical interventions using data from the PROSPERO registry. BMJ Open. 2017;7(2):e012545.

59. Sampson M, Barrowman NJ, Moher D, Klassen TP, Pham B, Platt R, et al. Should meta-analysts search Embase in addition to Medline? J Clin Epidemiol. 2003:56(10):943-55. 
60. Royle P, Milne R. Literature searching for randomized controlled trials used in Cochrane reviews: rapid versus exhaustive searches. Int J Technol Assess Health Care. 2003;19(4):591-603.

61. Morrison A, Polisena J, Husereau D, Moulton K, Clark M, Fiander M, et al. The effect of english-language restriction on systematic review-based metaanalyses: a systematic review of empirical studies. Int J Technol Assess Health Care. 2012;28(2):138-44.

\section{Publisher's Note}

Springer Nature remains neutral with regard to jurisdictional claims in published maps and institutional affiliations.

Ready to submit your research? Choose BMC and benefit from:

- fast, convenient online submission

- thorough peer review by experienced researchers in your field

- rapid publication on acceptance

- support for research data, including large and complex data types

- gold Open Access which fosters wider collaboration and increased citations

- maximum visibility for your research: over $100 \mathrm{M}$ website views per year

At BMC, research is always in progress.

Learn more biomedcentral.com/submissions 